\title{
Collaborative Innovation in Digital Ecosystem
}

\author{
Ihsanudin $^{1}$, Amy Y. S. Rahayu ${ }^{2}$ \\ \{ihsanudin.ui@gmail.com ${ }^{1}$, amy_soeroso@yahoo.com ${ }^{2}$ \} \\ Faculty of Administrative Science (University of Indonesia) $)^{1 \& 2}$
}

\begin{abstract}
Public sector innovation has been a hot topic of discussion. The traditional approach to public sector management has failed to solve the increasingly complex problems and we must not rely solely on the governments role. This paper claims that inclusive innovations are needed for the actors to perform collaboration. This is marked with paradigm shift in public administration which encourages collaborative innovation. This new approach is believed to serve as a solution to resolving complex problems. At the same time, digital ecosystem allows the government, private sector, society and nonprofit organizations to collaborate. This paper outlines the research findings on digital collaborative innovation on poverty reduction in Bandung city. The findings indicate that digital ecosystem can serve as a complementary arena that is more flexible for a collaboration process, but can not yet serve as a substitutional arena for direct collaboration. It is expected that this paper will shed light on further research direction.
\end{abstract}

Keywords: Collaborative Innovation, Public Administration, Digital Ecosystem, Poverty

\section{Introduction}

Innovation is a study that has become a hot topic of discussion, not only in the private sector but also in the public sector. The study of innovation has now found its momentum in the public sector due to the increasing public expectations towards public services. Innovation is considered as a popular terminology in the last decade as there is more and more demand from the society to urge for a change in public sector performance [1], so that innovation is unavoidable choice in public sector.

Before further elaborating on the discussion about innovation in the public sector, it is necessary to first understand the definition of innovation. New ideas are not necessarily termed as innovation, since there is often misleading assumption, which says that creativity will automatically produce innovation. Conceptually, innovation is different from creativity. Creativity includes new ideas, new challenges and new opportunities, while innovation is a phase where new ideas are potentially realized, trialled, pilot-projected, and evaluated [1].

There are three reasons why innovation is critical importance in public sector [2] [3] [4]: Firstly, the society has increased expectations towards public services but government's resources and capacity are inadequate; Secondly, public officials and elected politicians have increased ambitions towards public governance but it is difficult due to the increasing social, political and economic complexity; Thirdly, wicked problems are increasingly difficult to be solved simply by producing more expenditures and creating standard solutions.

Pertaining to innovation within the public sector, governance paradigm that exalt innovation is an important factor to reinforce the public sector and enhances efficiency and effectiveness of public service quality [4]. More specifically, the study of public sector innovation has become a hot debated issue and it is becoming more popular in the policy making agenda in various countries. 


\section{Collaborative Innovation in Governance Paradigm}

Collaboration is closely linked to the study of public administration, especially in the governance paradigm. The term governance emerged when the traditional model of a nation state failed to sufficiently describe the reality or reform of policy. There are two problems that can be positively solved by paradigm shift in public administration from government to governance which are overloaded government and ungovernable society [5]. It is believed that collaboration between the public and actors can achieve more effective objectives compared to that of performed by the government themselves.

Governance paradigm places the government not as a single actor in decision making to solve public problems. The era of governance has transformed intergovernmental relations beyond the scope of the government and the collaboration takes place among the government, private organizations, central government and local government in dealing with public problems. That is why a search for a better governance has become the spotlight in the current development issues [6].

There are three generations of governance study [2]. The first generation focuses on the contribution of network in the making of effective policies. Governance network facilitates the exchange of resources, coordination of policy initiatives and the development of policy solution; the second-generation focuses on the role of governance in policy democratisation through increased empowerment of participation, democracy deliberation and democracy ownership; the third generation focuses on the capacity of innovation in governance network and explores about how and why governance network can provide public innovation.

The discussion of public sector innovation is one of the focuses of the study of governance paradigm or also is known as new public service (NPS), or sometimes it is called new public governance (NPG). This paradigm stimulates the emergence of collaborative innovation for the improvement of public services quality [7]. Albeit not as popular as collaborative governance, the study of collaborative innovation has gained serious attention from a number of public administration scholars.

Nambisan defines collaborative innovation as a collaborative approach to innovation and problem solving within public sector by harnessing the resources and creativity of external networks and communities to escalate innovation in line with the expected outcomes [8]. Another defines collaborative innovation as "the innovation process is opened up, that actors from within the organization, other organizations, the private and third sector and citizens are integrated into the innovation cycle from the earliest stage onwards" [9]. Sørensen and Torfing define collaborative innovation as "a process of creative problem solving through which relevant and affected actors work across formal institutional boundaries to develop and implement innovative solutions to urgent problems" [10].

In principle, the definitions of collaborative innovation proposed by the above-mentioned scholars have meanings that go hand in hand. We recorded three important things of collaborative innovation. Firstly, collaborative innovation is a creative problem solving process. Secondly, various actors from across relevant and related institutions are involved. Thirdly, those actors create and implement innovative solutions to solve public problems. Therefrom, we define collaborative innovation a process to solve public problems in a creative and collaborative ways among relevant and related actors (public organizations, private organizations, non-profit organizations and societies) by harnessing the resources from the actors so that innovations are created and implemented in that better goals and benefits are achieved as opposed to the innovation created by a single public actor. 


\section{Collaborative Innovation in Digital Ecosystem}

Collaborative innovation in this paper refers to collaborative governance within the public sector innovation. If a collaborative governance is conducted with the objective of solving the problems incrementally [11]; [12], collaborative innovation is performed to deal with public problems through radical change [4]. That is why, the discussion of collaborative innovation can not be separated from an interactive arena [2] or face to face dialogue [11] conducted by the actors who perform direct collaboration.

At the same time, we claim that 'digital ecosystem' can be used as a more flexible collaboration arena. There is open source strategy [13] that can be used by public sectors and stakeholders to collaborate in creating collaborative innovation. Open source strategy is aimed at producing innovation using the internet to invite and to get co-creators. This strategy allows the involvement of resources in an innovative process efficiently.

In this section, we present the research results of digital collaborative innovation in poverty reduction in Bandung city through the program of Family for Family. This research is a qualitative study conducted from October 2017 to August 2018. The data were collected using in-depth interviews to informants involved in poverty reduction innovation including the mayor of Bandung, municipal office of social and poverty reduction of Bandung, non-profit organizations and private companies. The research findings indicate that digital ecosystem can serve as an arena for public, private and society to collaborate in tackling poverty issues.

The municipal government of Bandung has been seeing poverty as a difficult issue to overcome. This is demonstrated by poverty rate in Bandung city that experienced stagnation at 4 percent for the last four years (2014-2017). The root of the problem is that the mostimplemented programs are top-down and business as usual. As a result, the process of this policy program is at the government, the financing sources stem from the state finance which takes a long and complicated bureaucracy process and potentially causes inefficiency and the underprivileged society are not involved, in fact they are the ones who know best the needs of the poor. Innovative poverty reduction efforts different from that of the existing are necessary.

The municipal government of Bandung gradually produces innovation for poverty reduction, e.g. the program of Family for Family. This innovation program emerged "buttom up", that is the results of collecting society's aspirations. In addition, the financing for poverty reduction through the Innovation of Family for Family program is not sourced from the State Budget or Local Budget. The financing of this program is sourced from donor families who provide assistance to underprivileged families. This innovation does not merely involve public sectors, but also societies, private and non-profit organizations for reducing poverty.

The effort to connect the donor families with the underprivileged families is facilitated in a crowd-funding community platform website called kitabisa.com which provides progress report on a periodic basis of the donor/recipient family. The donation is granted by the donor families in the forms of materials, providing job opportunities and childrearing. The assistance provided is transparently reported, including the output and the outcome of the program. This innovations are created to solve problems in a region by harnessing existing potentials. This means the different leadership style creates the different innovation [14].

The coordination was conducted between Ridwan Kamil and kitabisa.com in digitilizing innovation for tackling poverty. The Mayor of Bandung requested the assistance from kitabisa.com experts to create a special website. Based on the data obtained from the interview, the Mayor of Bandung admitted that the coordination for this program is not intensively conducted. The Mayor believes that it would be a good idea if the government provides only mild intervention in the social movement such as Family for Family. 
Despite the mayor's constraint in being able to consistently conduct coordination in this program, he has futuristic thinking. The people of Bandung city has actively created their own solutions, that all they need is an access to perform collaboration. At present, people can perform digital interaction through the websites kitabisa.com and familyforfamily.id which serve as an effective platform. This indicates that the civil society in Bandung city has been shaped and thus shows a positive thing.

From the investigation conducted, it was found that it is extremely difficult to execute ideas that have been initially proposed. It is not easy for a privileged family to directly adopt underprivileged family. An adaptation is required, since each family has their own activities, especially that of the privileged family. The problem lies in the fact that they have work to do, and each family lead a different way of life. In the end, assistance from the family is provided through donation only. This donation is managed by a team of Family for Family program through the websites kitabisa.com and familyforfamily.id and the donors will wait for the report and the progress of the underprivileged family.

Furthermore, the most intensive coordination occurs between the priviledged family together with a team of family for family and underprivileged family. This coordination is the focal point of community involvement as citizens [15] from collaborative innovation in tackling poverty. The team of Family for Family displays profiles of underprivileged family on the website kitabisa.com and familyforfamily.id, so that the privileged family can choose which underprivileged family is to be assisted. Afterwards, they will be given options of whether to take care of the family directly or hand them over to the team of Family for Family.

Although this collaborative innovation is digitally based, direct interaction among the actors is still necessary. This can be seen from the facilitation of society's wishes to provide assistance to tackle poverty upon meeting with the Mayor of Bandung. Then the aspiration was followed up with the instruction from the Mayor to Municipal Office of Social and Poverty reduction to prepare approximately a thousand data on underprivileged families and to launch this innovation program. Direct coordination was also conducted in the form of website management by the Mayor and kitabisa.com and the team of Family for Family. The society and a team of volunteers play a central role in coordinating the privileged family and underprivileged families and providing entrepreneurship training. Private companies are also involved in providing jobs for underprivileged families.

After a year of the implementation of collaborative innovation, there has been a total of 132 underprivileged families (of 1000 target families) who have received help on education and health, and they now have jobs/businesses. The field data show that there is a tendency for the privileged family to choose underprivileged single-mother family to be assisted. On kitabisa.com and familyforfamily.id the profile of underprivileged families are displayed for the donor family to choose from. Assistance in this program is provided in the forms of businesses, education and health.

\section{Conclusion}

This paper aims to explain that digital ecosystem can support collaboration process among the actors from the public sectors, private sectors, society and non-profit organizations in collaborative innovation. The findings of our study on digital collaborative innovation on poverty reduction in Bandung city demonstrate that open source strategy generates great benefits in the collaboration process among the actors through a website. We concluded that digital ecosystem can serve as a complementary arena for collaboration process and can not yet serve as a substitutional arena for direct collaboration (face to face). Digital collaborative 
innovation can promote a more flexible collaboration process, since the actors have limited time in ensuring a long-term collaboration. It is expected that the findings of this research shed light on further research direction.

\section{References}

[1] A. Y. S. Rahayu, Manajemen Perubahan dan Inovasi, Jakarta: UI-Press, 2015.

[2] E. Sørensen and J. Torfing, Collaborative Innovation in the Public Sector: An Analytical Framework, Roskilde: Roskilde Universitet, 2010.

[3] E. Sorensen and J. Torfing, "Introduction: Collaborative Innovation in the Public Sector," The Public Sector Innovation Journal, vol. 17, no. 1, pp. 1-14, 2012.

[4] E. Sørensen and J. Torfing, "Metagoverning Collaborative Innovation in Governance Network," American Review of Public Administration, vol. 47, no. 7, pp. 826-835, 2017.

[5] B. G. Peters and J. Pierre, "Governance, Accountability and Democratic Legitimacy," in Governance and Democracy: Comparing National, European and International Experiences, London \& Newyork, Routlege, 2006, pp. 29-43.

[6] I. Jamil, S. Askvik and T. N. Dhakal, "Introduction," in In Search of Better Governance in South Asia and Beyond, New York, Springer, 2013, pp. 1-12.

[7] E. Sørensen and J. Torfing, "Enhancing Public Innovation through Collaboration, Leadership and New Public Governance," in New Frontiers in Social Innovation Research, New York, Palgrave Macmillan, 2015, pp. 145-169.

[8] S. Nambisan, Transforming Government Through Collaborative Innovation, New York: IBM Center for the Business of Government, 2008.

[9] B. Bommert, "Collaborative Innovation in The Public Sector," International Public Management Review, vol. 11, no. 1, pp. 15-33, 2010.

[10] E. Sørensen and J. Torfing, "Co-initiation of Collaborative Innovation in Urban Spaces," Urban Affairs Review, Vols. -, no. -, pp. 1-31, 2016.

[11] C. Ansell and A. Gash, "Collaborative Governance in Theory and Practice," Journal of Public Administration Research and Theory, vol. 18, no. 4, pp. 543-571, 2008.

[12] J. D. Donahue and R. J. Zeckhauser, Collaborative Governance: Private Roles for Public Goals in Turbulent Times, New Jersey: Princeton University Press, 2011.

[13] B. Eggers and S. Singh, The Public Innovators Playbook, Washington D.C.: Harvard Kennedy School of Government, 2009.

[14] L. Safrony, Manajemen dan Reformasi Pelayanan Publik dalam Konteks Birokrasi Indonesia, Yogyakarta: Aditya Media Publishing, 2012.

[15] E. Sørensen and J. Torfing, "Collaborative Innovation in the Public Sector," in Enhancing Public Innovation by Transforming Public Governance, New York, Cambridge University Press, 2016, pp. 117-138. 